\title{
Prosas sin finalidad
}

\author{
EL REPARTIDOR DE ILUSIONES ...
}

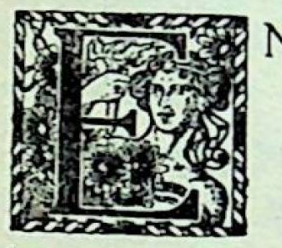

un tiempo pensé seriamente si la ocupación más elevada que conviniera a un espíritu inquieto y generoso - como pretendía ser el miono sería repartir un poco de ilusión, de alegre frágil y volandera ilusión, por los monótonos caminos del mundo. Creía que este mundo tan viejo, arrugado por la meditación y la duda, hastiado de los placeres y los dolores que se repiten, no requería ya más ciencia, ni más conocimiento. ni más verdades, sino una emoción liviana - que lo distrajera sin obligarlo a pensar-, como esa ingenua música de los circos. que en nuestra infancia nos parecía preludio del espectáculo maravilloso que daban los titiriteros y después, después que conocimos a Wagner y a Beethoven, continuábamos escuchando con simpatia.-Era un poco de nuestra alma antigua, sencilla, crédula, bondadosa y fantaseadora la que vagaba en esos ligeros compases que todos podian traducir según su estado de ánimo-alegre. melancólico - según el tiempo-frio. caluroso: según las ideas que entonces nos dominaran. - A las cosas más abstractas era adaptable como los estribillos.

$\mathrm{Y}$ pensé en los medios que yo podría tener para realizar mi caritativo propósito de ilusionar al mundo._- Pensé en el Arte; pero el arte. desde que se ha convertido en el más difícil y caprichoso artificio, se ha aislado en las oscuras capillas como un avaro, y no tendrá sugerencia alguna sobre esas almas simples y hermosas -los labriegos. los niños, las muchachas de aldea-que yo queria impresionar.$\mathrm{Ni}$ para nuestras multitudes incrédulas y excépticas-nuestras multitudes que leen manuales científicos y están suscritas a la Biblioteca Sociológica-seria eficaz un arte primitivo. lleno de verdades rudimentarias y de misterios cósmicos como aquél que las manos puras del Giotto pintaran en las bóvedas de Santa Maria Novella, y Dante en su fantástico poema.-Ilustres doctores se encargarian de descomponerlo en sus sutiles laboratorios: de apagar las lucecillas de ilusión que despertara en las almas para dejarlas sumidas en la duda, en la oscuridad. - Ni era tampoco la Ciencia mi objetivo: esta ciencia que violando misterios y secretos. descubriendo y ofreciéndonos todo, está a punto de convertir al hombre en un rey pletórico, sedentario y aburrido. 
Miré entonces a esas profesiones humildes y errantes - la del buhonero. la del titiritero, la del organillero-que ante el desdén de las gentes egoístas y graves, arrostran los caminos de Dios repartiendo el contento en las aldeas internadas y en los hombres ignorantes, - Y pensaba en el alegre circo de payasos que deslumbrara mi niñez. - Eran como figuras escapadas de un iluminado libro de estampas, los equilibristas vestidos de azul o roja malla; las rubias saltarinas muchachas trepando sobre los briosos poneys, el que hacía de malabarista chino, sacando de sus manos como de un cesto inagotable volanderas cintas de todos colorcs: los clowns que se ahogaban entre sus tiesas golillas y abombados pantalones, los clowns cuyos nomhres ya invitaban a la risa... Anatolio, Cantalicio. Anacleto... En aras de la rubia italianita de las piernas hermosas, sacrificamos en boletos para la función todos los mezquinos centavos que conseguiamos entonces.Ella nos dió la primera y electrizante visión de belleza.-Y comparándola con las timidas y pacatas muchachas de nuestro pueblo. iqué desmirriadas y tristes nos parecian éstas con las faldas largas, las telas opacas y los antipáticos cuellos ‘Maria Stuardos, de moda entonces! Nuestra alma adolescente que aun no sabía de leyes morales ni hábitos sociales, hubiera querido-en un arranque de estética iconoclasta- que todas las muchachas llevaran, como Dorina, una trasparente malla rosada y lucieran las piernas desnudas.

En el buhonero pensaba, que con su caja de sorpresas y maravillas, cansado el cuerpo. pero contenta el alma, tarareando una canción caminera, llegaba a los escondidos caserios.-iLlegó el buhonero! Y las muchachas y las viejas abandonan los sembrados donde hacian la deshoja del maíz, para ir a comprarle el vistoso pañuelo que lucirán en la próxima fiesta; la efigie del santo que es patrono de las buenas cosechas, el espejito donde mirarse, la brillante sortija de abalorio, que a fe del buhonero no se oxida, como las de oro fino.-En estas ferias siempre toca a los chicos una corneta, una armónica, un trompo... Y en el organillero que ante el estrépito de las grandes ciudades, junto a la febril multitud que pasa a sus negocios, sus quehaceres y sus ambiciones, toca en su pianito las olvidadas músicas de antaño: no cesa de tocar aunque los carruajes le cerquen y la multitud le empuje, como enseñando a aquellos hombres apresurados que todo no es el minuto presente ni el negocio que ahora les perturba... que hay que dar algo al recuerdo, a la música, a la meditación y al sentimiento. - Siempre habrá un muchacho desocupado y un viejo poeta romántico que le escuchen.

Pero los respetos. prejuicios y conveniencias que han inventado los hombres para aburrirse y entristecerse más, retardaron hasta ahora mis propósitos.-Olvidando los propios dolores voy poniendo un poco de ilusión en estas prosillas hasta que me resuelva a salir por los caminos a repartirla, a esparramarla sobre las almas diáfanas-de los niños, de los viejos, de las muchachas aldeanas-, como esas flores silvestres que los labriegos arrojan al paso de la procesión. 